Research Article

\title{
Introduction of Fusarium species associated with crown and root of canola in Lorestan Province of Iran
}

\author{
MARYAM MIRDERIKVAND, MOSTAFA DARVISHNIA ${ }^{凶}$, \\ EIDY BAZGIR, SAMIRA PAKBAZ
}

Department of Plant Protection, Faculty of Agriculture and Natural Resources, Lorestan University, Khorramabad, Iran

Received: 12.03.2021

Accepted: 24.07.2021

Mirderikvand M, Darvishnia M, Bazgir E, Pakbaz S (2021) Introduction of Fusarium species associated with crown and root of canola in Lorestan Province of Iran. Plant Pathology Science 10(1):64-75. Doi: 10.2982/PPS.10.1.64.

\section{Abstract}

Introduction: Canola is one of the most important oilseeds in the world. Fusarium species can causes of canola root and crown rot. Material and Methods: In order to identify Fusarium species associated with rapeseed, some samples of the roots and crown of infected and suspicious plants were taken from rapeseed fields in the counties of Lorestan Province during the 2018 growing season. The samples were transferred to the laboratory and pathogenic fungi isolated and purified using specific and public media and then identified with valid keys. Results: A total of 88 isolates were obtained from the collected samples, which due to the morphological characteristics as $F$. acuminatum, $F$. culmorum, $F$. diversisporum, $F$. oxysporum, $F$. sambucinum, and $F$. solani. F. culmorum with 21 isolates $(23.86 \%)$ and $F$. solani with 7 isolates $(7.95 \%)$ had the highest and lowest frequency percentage, respectively. Conclusion: Canola is reported for the first time as a new host for $F$. diversisporum and $F$. sambucinum in Iran.

Key words: Canola, Fusarium, Root rot

$\checkmark$ Darvishnia.m@lu.ac.ir 


$$
\text { مقاله يروهشى }
$$

\section{معرفى كونههاى Fusarium همراه طوقه و ريشه كانولا در استان لرستان ايران}

مريم ميردريكوند، مصطفى درويشنيا ه • عيدى بازگير، سميرا پاكباز

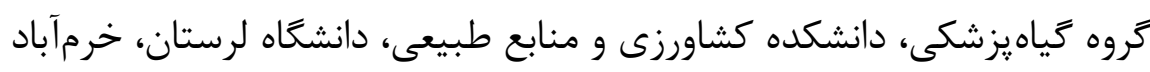

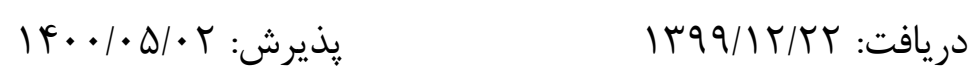

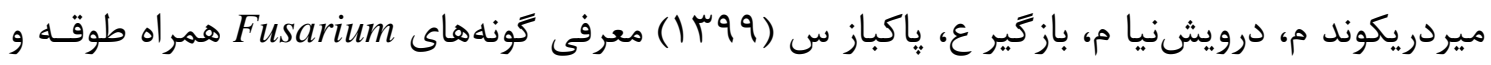

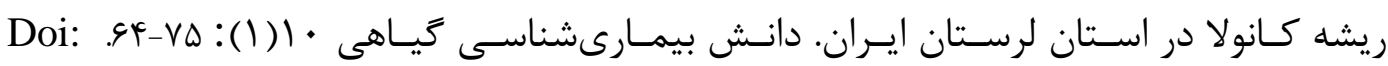

مقدمه: كانولا يكى از زياهان روغنى مههم در جهان است. گونههاى Fusarium مىتوانند باعث يوسيدگى ريشه و طوقه كانولا شوند. مواد و روشها: بلمنظور شناسايى گونههاى Fusarium همـراه

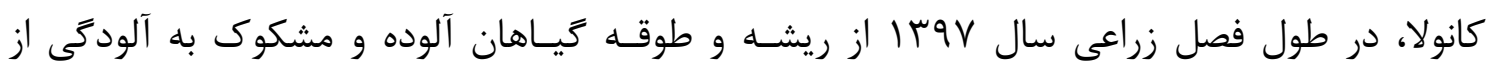
مزرعههاى كانولا حومه شهرستانهاى استان لرستان نمونهبردارى صورت گرفت. نمونهها به آزمايشعاه

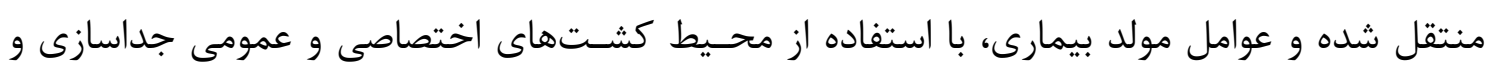

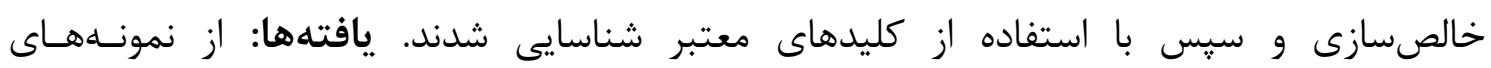

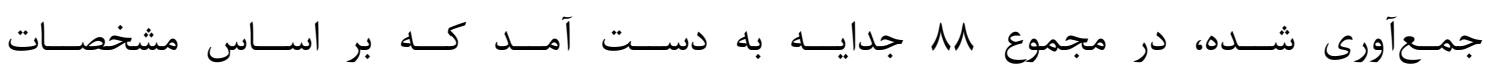
ريخــت شناختى F. solani g. sambucinum F. oxysporum،F. diversisporum F. culmorum بيشترين وكمترين درصد فراوانى را داشتند. نتيجه

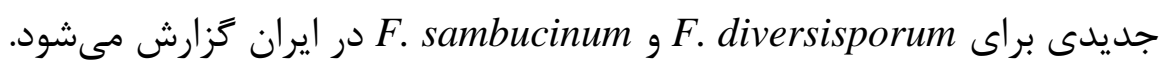

Fusarium وازَّان كليدى:يوسيد

\section{Introduction}

مقدمه

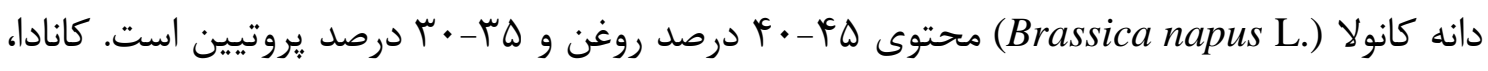
جين، هندوستان، فرانسه و آلمان در حال حاضر كشورهاى عمده توليدكننده كانولا مىباشند كه در ساير كشورها نيز در حال توسعه است (Kimber and McGreogor 2004 ). كانولا به عنوان يكى از مهرمترين كياهان روغنى در جهان محسوب مىشود. اين زياه در شرايط آب و هوايى مناطق مختلف

$\triangle$ Darvishnia.m@lu.ac.ir 
ايران قابليت كشت و كسترش دارد. كانولا نيز مانند ساير گياهان زراعى بيمارىهاى فراوانى دارد كه در نقاط مختلف جهان كم و بيش باعث كاهش توليد آن مىشود (Azizi et al. 1999 ). كونههاى يكى از عوامل يوسيدگى ريشه و طوقه كانولا مىباشند، كه با توليد متابوليتهاى ثانويه

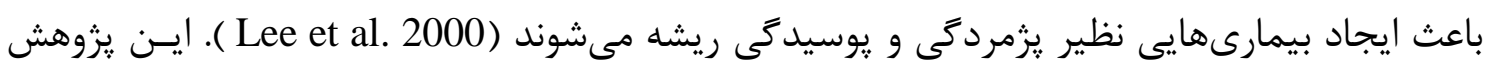
به دليل اهميت اين قارجها در يوسيدگى ريشه و طوقه كانولا در سطح استان لرستان صورت گرفت.

\section{Material and Methods}

مواد و روشها

مزرعههاى حومه شهرستانهاى الشتر، خرمآبان، ويسيان، پلدختر، دوره و معمولان در طول فصل زراعى سال Vوسا بازديد شدند و از بوتههاى بيمار و مشكوى به آلودگى با علايم يزمردگى و يوسيدگى ساقه، طوقه و ريشه، وه نمونه جمعآورى و در داخل كيسه كاغذى قرار داده شدند. پس از انتقال نمونسههـا به آزمايشخاه و نكخهدارى در يخجال، جداسـازى قارجها با اسـتفاده از محـيط كشـت اختصاصسى Nash and Snyder و محسيط كشت عمومى PDA (عصاره سيب زمينى دكستروز آكار) از قسمتهاى طوقـه و ريشـه صورت كرفت. خالصسازى جدايهها با استفاده از روش تك هات كردن روى محيط آب آكار (WA) دو درصـد انجـام شـد. هاگزايى جدايهها روى محيطهاى CLA و SNA و

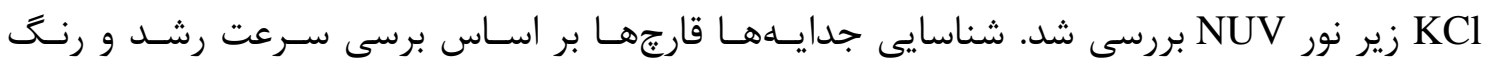
ير كنه و مطالعه مشخصات ريختشناختى (شكل ماكرو و ميكروكنيديومها، شكل فياليد، تشكيل يا عدم تشكيل كلاميدوسيور، آرايش ميكروكنيديوم در انتهاى فياليد) با ميكروسكوب اليميوس BX51 كاليبره شده و مجهز به دوربين و با استفاده از كليدهاى معتبر شناسايى گونههاى Fusarium صـورت

كرفت (Gerlach and Nirenberg 1982, Nelson et al. 1983, Leslie and Summerell 2006).

\section{Results and Discussion}

از ريشه و طوقه كانولا در مجموع M M جدايه از كونههاى Fusarium به دست آمد كه بـر اسـاس خصوصيات ريختشناختى شش گونه به شرح زير شناسايى شدند.

\section{Fusarium acuminatum Ell. and Kellerm.}

ميزان رشد ير گنه قارج روى محيط كشت PDA بعد از • ا روز در دماى فT درجه سلسيوس V-N/F

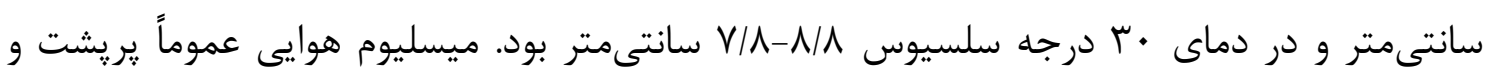

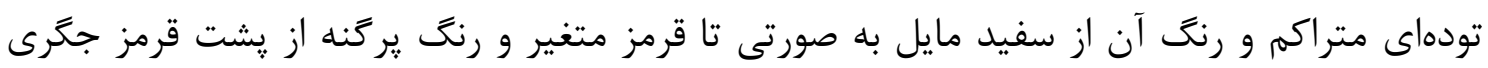
(كارمن) است. كنيديوفورها به صورت منوفياليد ساده جانبى و منشعب و كاهى كوتاه و فراهم تشكيل 


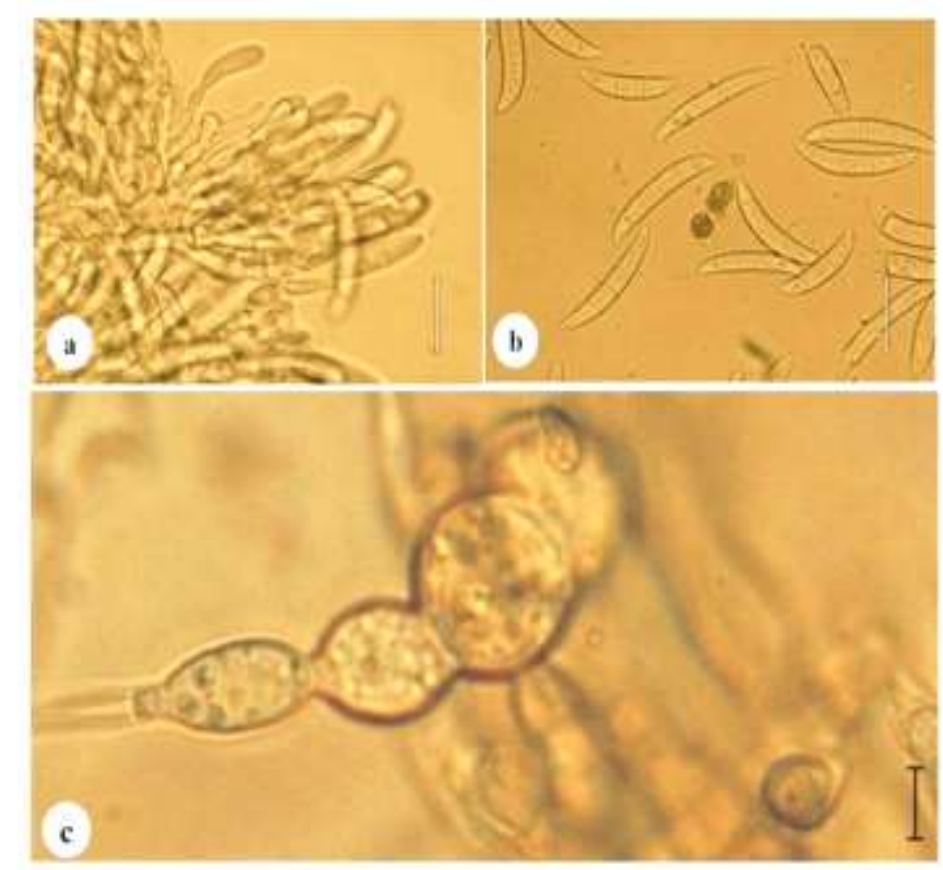

شكل l. Fusarium acuminatum: منوفياليد منشعب، b- b- ماكروكنيديوم، c- م- كلاميدوسيور.

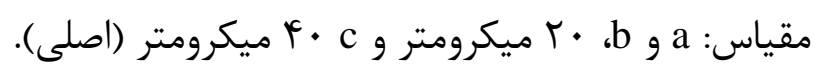

Figure 1. Fusarium acuminatum: a- Branched monophialids, b- Macroconidia. cChlamydospore. Scale: a, b $20 \mu \mathrm{m}$ and c $40 \mu \mathrm{m}$.

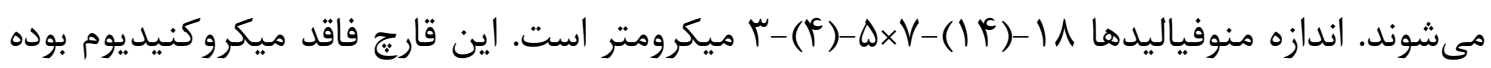

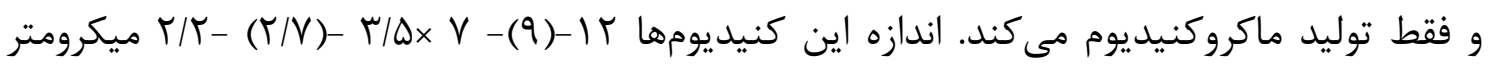

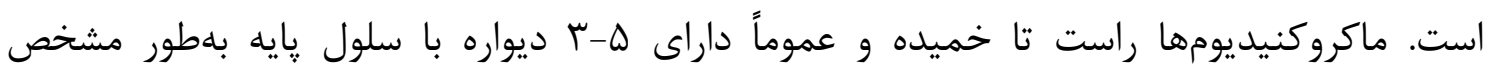
ياشنهاى و سلول انتهايى باريك و منقارى شكل خميده است. اندازه ماكروكنيديومها سه ديواره ^ץ -

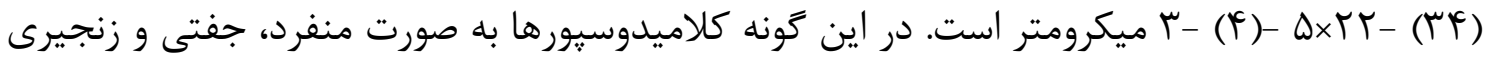
Booth 1971, Gerlach and ) تشكيل مىشوند (شكل (). مشخصات اين قارج با آنجه در منابع Nirenberg, 1982, Nelson et al. 1983, Burgess et al. 1994, Seifert 1996, Leslie and F. مر مورد اين زونه ذكر شده مطابقت دارد. ززارشاتى وجود دارد كه 2006 (Summerell acuminatum يوسيد گى طوقه و ريشه در زياهان به خصوص لخومها مىشود (Leslie and Summerell 2006 ). اين كونه در ايران از گندم در لرستان، گركان و رشت، آذربايجان غربى و كرمانشاه گزارش شده است Zare and Ershad 1997, Darvishnia et al. 2010, Ravanlou 2000, Mansoori et al. 2002, ) 


\section{Fusarium diversisporum Sherb.}

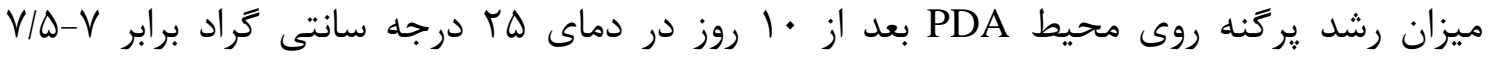

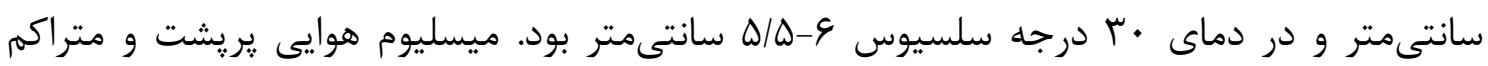
קنبهاى و به رنت سفيد مايل به صورتى مىباشد و رنت سطح زيرين :ركنه صورتى تا صورتى مايل به قرمز است. اسيورودوكيوم نارنجى رنت روى محيط CLA به وفور تشكيل شد. كنيديوفورها منوفياليد

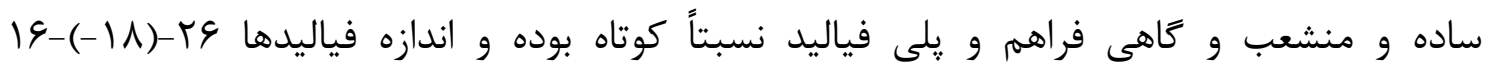
ميكرومتر است. اين گونه فاقد ميكروكنيديوم است. ماكروكنيديومها باريك، كشيده و با دو انتهاى خميده و به شكل S بوده و غالباً ه-r بندى مىباشند و ياخته انتهايى خميده و كشيده و ياخته يايه

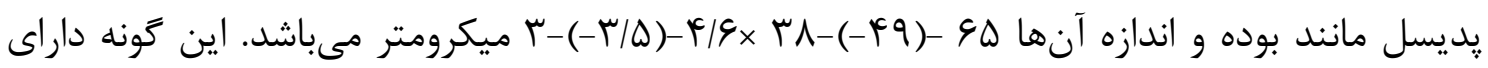
كلاميدوسيور بوده و كاهى كلاميدوسيور در ريسهها و كنيديومها تشكيل مىشود (شكل r). مشخصات اين كونه با آنجه در منابع ( Gerlach and Nirenberg 1982, Nelson et al. 1983, مشئ ذكر شده مطابقت داشت. اگرجه نلسون و همكاران (Summerell et al. 2003 (1993) اين گونه را به عنوان F. diversisporum توصيف نكرده و آن را Femitectum دانستهاند. اين گونه در ايران از روى كندم و جو جداسازى و گزارش شده است (Ershad 2010, Vafaei et al. 2001 ). اين گونه براى

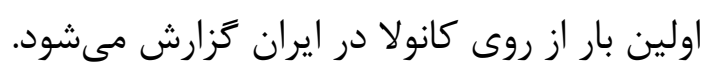

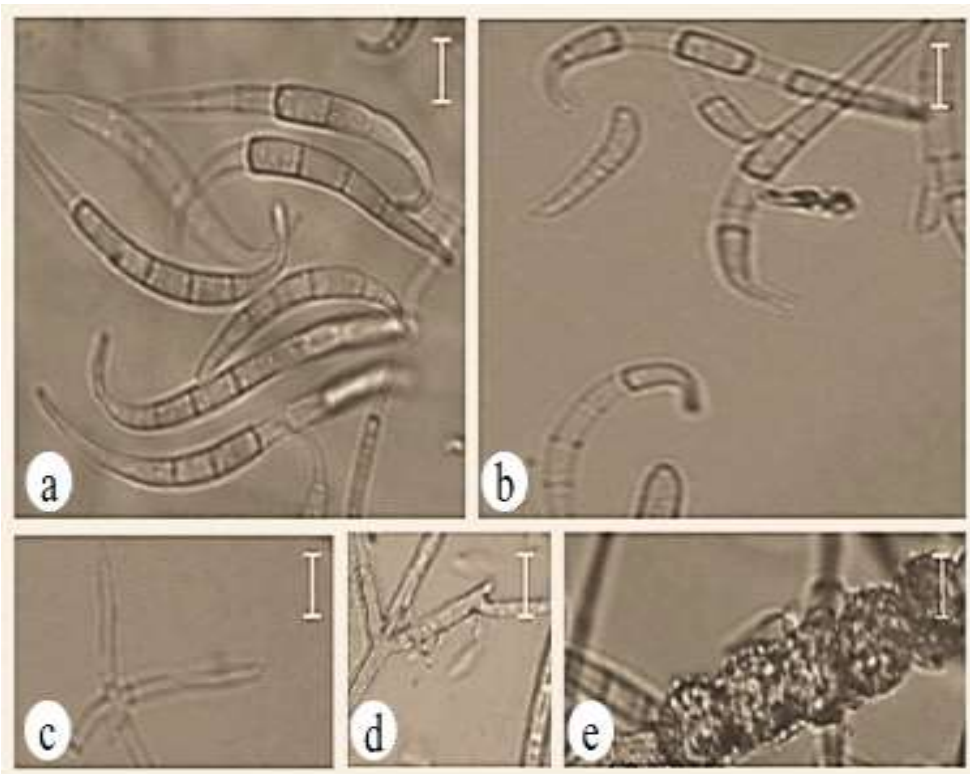

شكل r. Fusarium diversisporum و a : b- ماكرو و ميكروكنيديوم، c- منوفياليد منشعب، d-

$$
\text { يلىفياليد و منوفياليد، e-كلاميدوسيور. مقياس: · • ميكرومتر (اصلى). }
$$

Figure 2. Fusarium diversisporum: a and b- Macro and microconidium, c- Branched monophialid, d- Poly and monophialid, e- Chlamydospore. Scale: $10 \mu \mathrm{m}$. 


\section{Fusarium oxysporum Schltdl.}

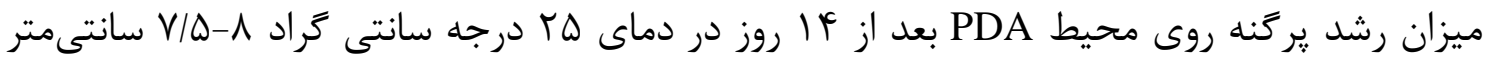
است. رنت سطح زيرين يرگنه متنوع و از سفيد تا بنفش تيره متغير بوده و داراى ميسليوم هوايى ريى فراوان و باصورت ينبهاى و در برخى جدايهها به مقدار كم تشكيل شده و به رنت سفيد تا سفيد مايل به بنفش و در مركز به صورت سفيد مايل به بنفش تيره مىباشد. كنيديوفورهاى اين زونه به صورت

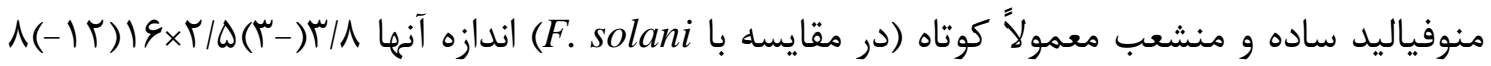
ميكرومتر، ميكروكنيديوم در اين قارج به وفور و بهصورت تك سلولى و به اشكال تخم مرغى، بيضوى و

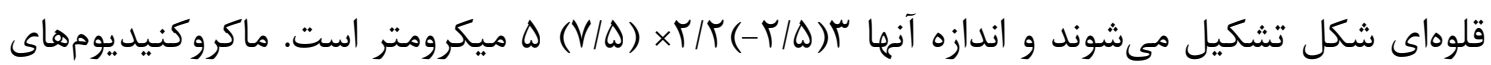
سيلندرى و كمى خميده و نوك تيز در دو انتها كمى باريك شده، سلول انتهايى ماكروكنيديوم

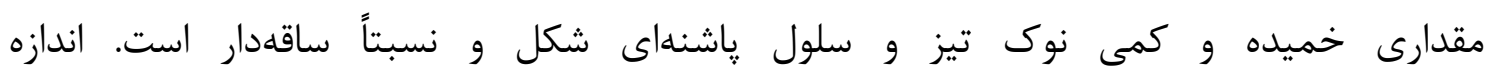

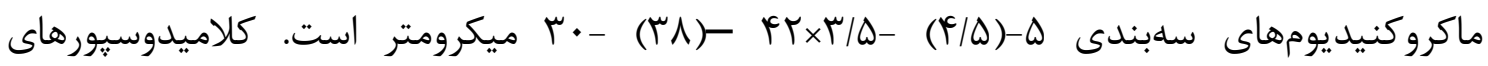
ريسهاى و كنيديومى روى محيط PDA و CLA به فراوانى و به صورت منفرد، جفتى و با سطح صاف يا خشن تشكيل مىشوند (شكل ب).

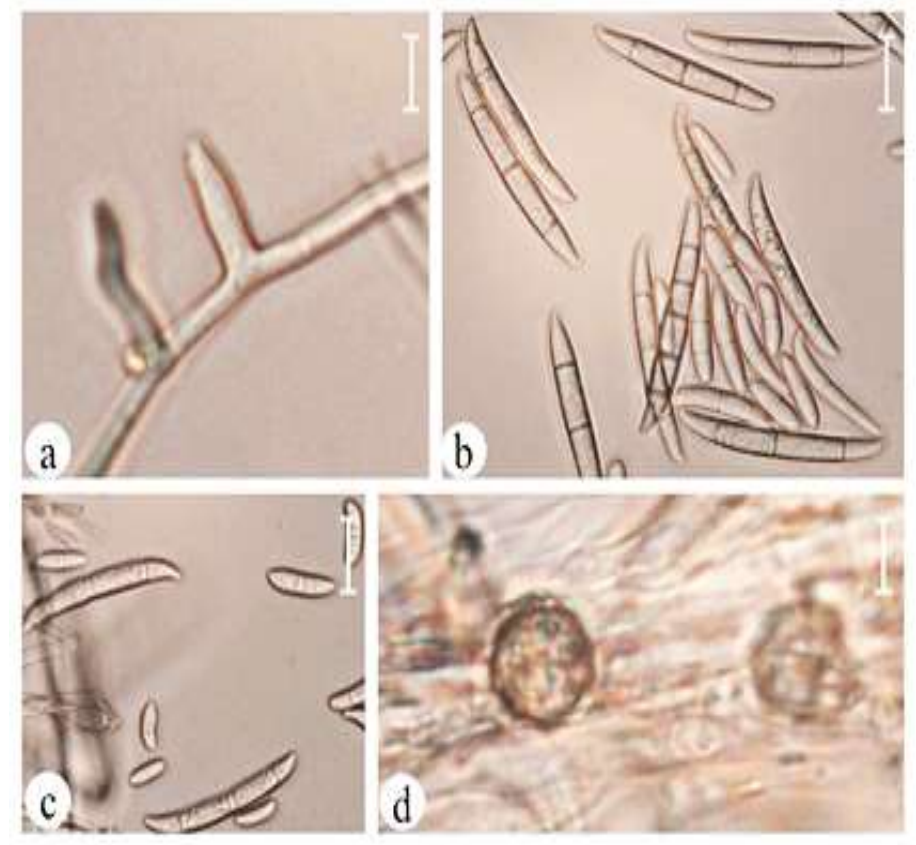

شكل س. Fusarium oxysporum: منوفياليد، b- b- ماكروكنيديوم، c- ماكرو و ميكروكنيديوم، d- كلاميدوسيور. مقياس: · ب ميكرومتر (اصلى).

Figure 3. Fusarium oxysporum: a- Monophialid, b- Macroconidium, c- Macro and microconidium, d- Chlamydospore. Scale: $20 \mu \mathrm{m}$. 
Booth 1971, Gerlach and Nirenberg 1982, Nirenberg and ) مشخصات اين گونه با منابع (O'Donnell 1998, Leslie and Summerell, 2006, Nelson et al. 1983 يراكنش جغرافيايى وسيع و اهميت اقتصادى زيادى به سبب بيمارىهاى مختلفى از جمله يزمردكى، Leslie and ) انسداد آوندى، مرى گياهجه، يوسيدگى طوقه و ريشه در زياهان مىشود، دارد 2006 Summerell). اين گونه در ايران از كندم، جو، ذرت و يولاف، سيب زمينى، زيره سبز، توت

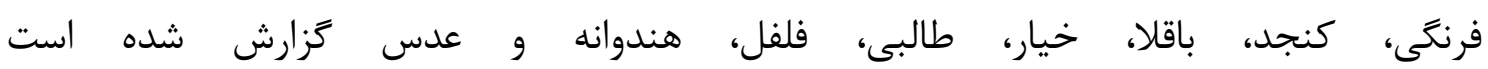
.( Darvishnia 2006, Ershad 2010, Larki and Farokhi Nejad 2015)

\section{Fusarium solani (Mart.) Sacc.}

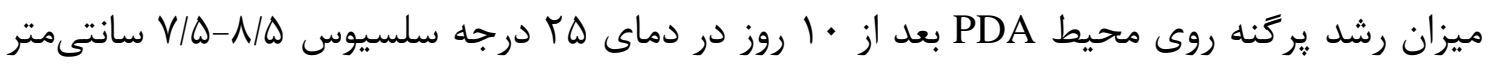
است. رنت سطح زيرين يركنه قرمز تا قهوهاى و در برخى جدايهها زرد مايل به قهوهاى و داراى ميسليومهاى هوايى فراوان و به صورت ينبهاى و گاهى نمدى به رنت سفيد تا سفيد مايل به صورتى و در مركز به صورت سفيد مايل به صورتى تا قهوهاى و برجسته مىباشد. كنيديومبرهاى اين كونه به

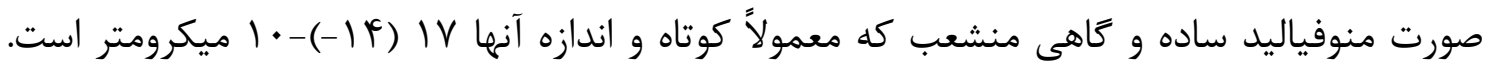

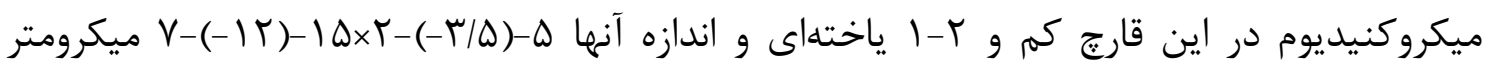
است. ماكروكنيديومها به فراوانى در اسيوردوكيومهاى نارنجى رنگ تشكيل مىشوند. ماكروكنيديومها

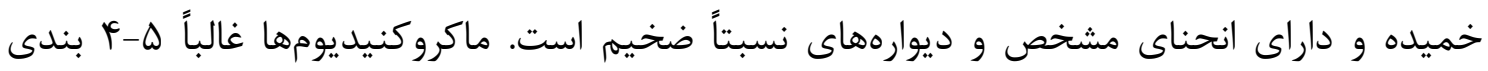
بوده و اندازه آنها MN CLA به فراوانى و به صورت منفرد، جفتى با سطح صاف يا خشن تشكيل مىشوند (شكل \&). مشخصات جدايههاى فوق با توصيفات اين گونه در منابع ( Booth 1971, Burgess et al. 1994, Gerlach and Nirenberg 1982, Nelson et al. 1983, Seifert 1996, Summerell et al. 2003,

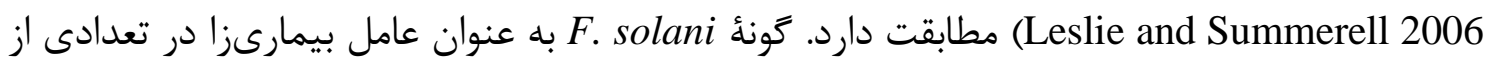
لكومها، مركبات، آوكادو، نخودفرنكى، اركيد، فلفل، سيبزمينى و بادمجان گزارش شده است. اين گونه به عنوان عامل بيوكنترل عليه فرفيون، دارواش و عامل يزمردگى گوجهفرنكى همانند ساير عوامل بيوكنترل و Trichoderma بهكار رفته است (Leslie and Summerell 2006). اين گونه در ايران از كانولا، كندم، جو، ذرت و يولاف، سيب زمينى، زيره سبز، توت فرنكى، كنجد، باقلا، خيار، طالبى، فلفل، هندوانه و عدس (Darvishnia 2006, Ershad 2010, Larki and Farokhi Nejad 2015 ) كزارش ته 

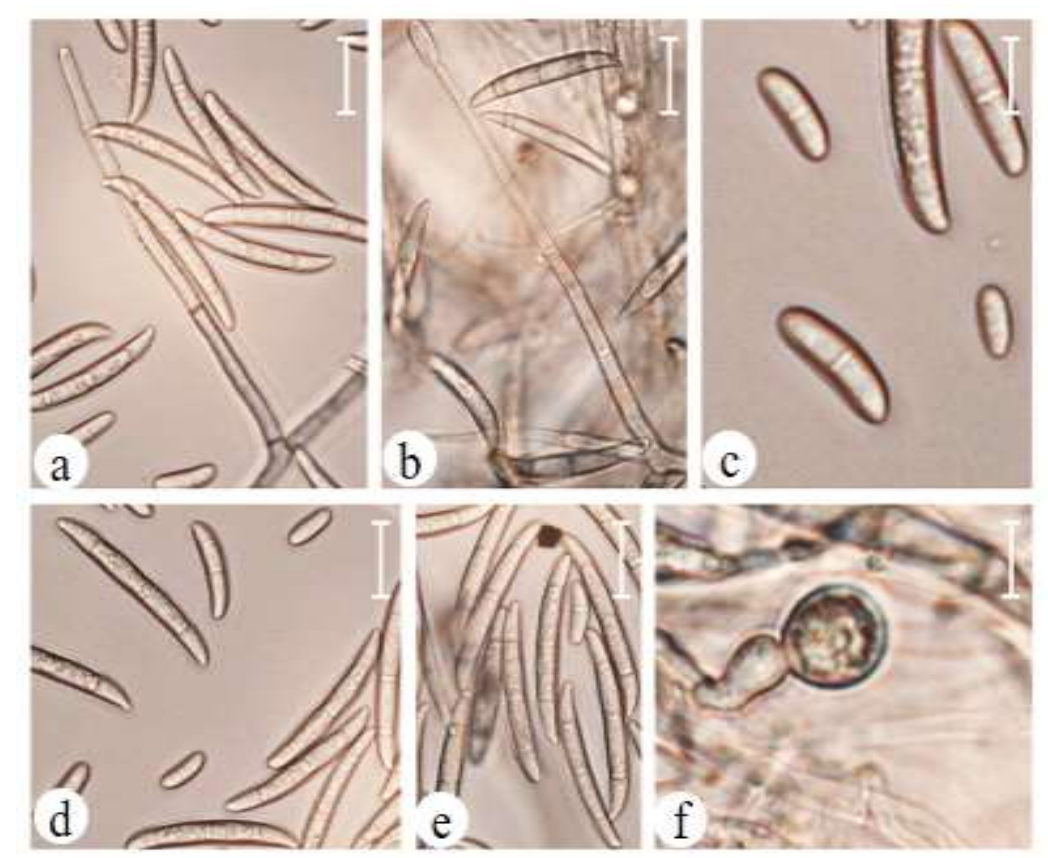

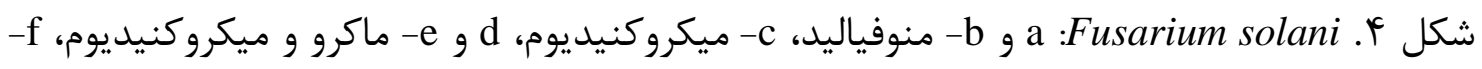
كلاميدوسيور. مقياس: · r ميكرومتر (اصلى).

Figure 4. Fusarium solani: a and b- Monophialid, c- Microconidium, d and e- Macro and microconidium, f- Chlamydospore. Scale: $20 \mu \mathrm{m}$.

\section{Fusarium sambucinum Fuckel}

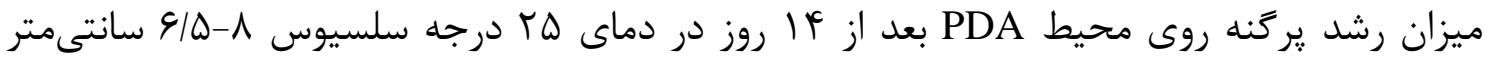
است. رنت سطح زيرين زيرگنه روى سفيد تا زرد گوگردى و در برخى جدايهها قرمز تا قرمز مايل به قهوهاى و داراى ميسيليوم هوايى فراوان و به صورت ينبهاى و كاهى نمدى به رنت سفيد تا قرمز و كاهى قهوهاى كمرنت مىباشد. كنيديوفورهاى اين گونه به صورت منوفياليد ساده و منشعب كه

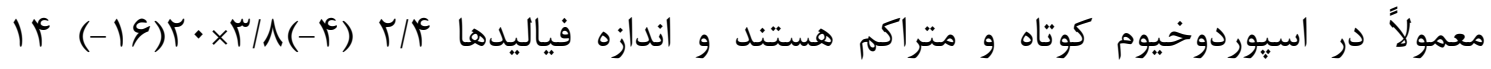
ميكرومتر است. ميكروكنيديوم در اين قارج كم و يا تشكيل نمىشود. ماكروكنيديومها نسبتاً كوتاه با سطح پشتى و شكمى خميده و از نظر شكل و اندازه تنوع زيادى دارند. سلول انتهايى نوى تيز نسبتاً

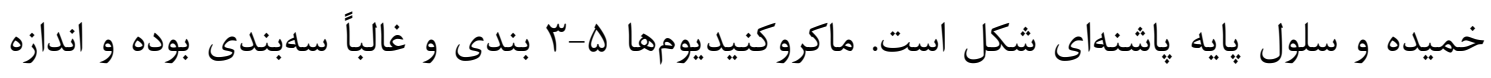

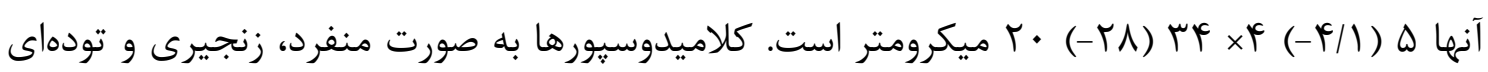
با سطح صاف تشكيل مىشوند (شكل ه).

Booth 1971, Gerlach and Nirenberg 1982, ) مشخصات گونه فوق با شرح موجود در منابع Nelson et al. 1983, Burgess et al. 1994, Nirenberg and O'Donnell 1998, Leslie and 

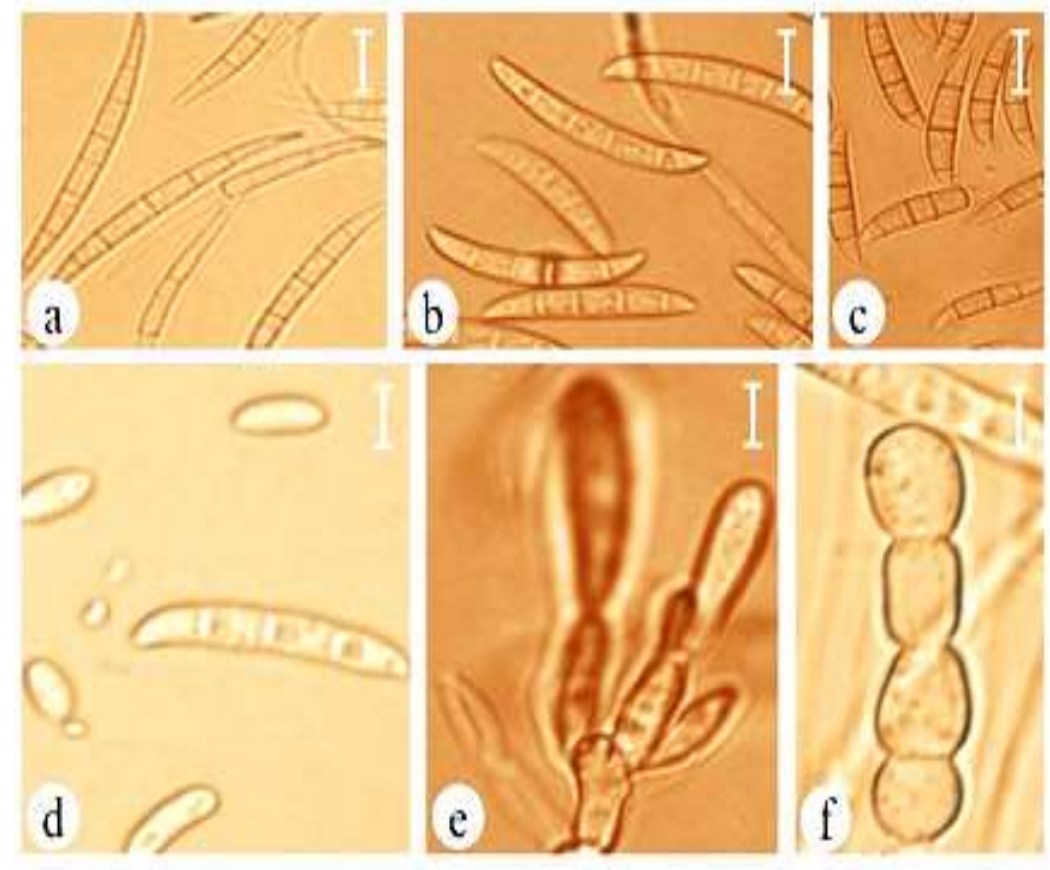

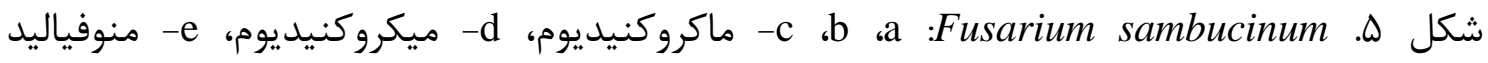
منشعب، f- كلاميدوسيور، مقياس: • • ميكرومتر (اصلى).

Figure 5. Fusarium sambucinum: a, b, c- Macroconidium, d- Microconidium, eBranched monophialid, f- Chlamydospore, Scale: $10 \mu \mathrm{m}$.

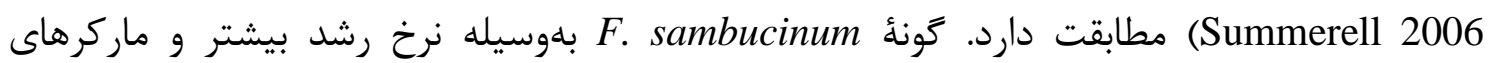

مولكولى از F. torulosum و F. venenatum متمايز مى گردد (2006 Leslie and Summerell ). كونهُ F. sambucinum سبب بيمارى يوسيدگى خشك غده سيبزمينى شده و در سيبزمينىهاى مقاوم توليد فيتوالكسينهاى ريشيتين و لوبيمين مى كند و اين قارج از زياهان مختلف از جمله يونجه، غلات، كلم، شبدر و سويا گزارش شده است. همجنين توليد انياتين، تريكوتسين، بيوريسين، فوزارين، فوزاريكى اسيد، سمبوتوكسين و ورتمانين و ماده ضدقارجى Fusacandins كه از سنتز بتاكلوكان در قارج Candida albicans جلوگيرى نموده، توليد مى كند (Leslie and Summerell 2006 ). اين كونه قبلاً از لوبيا در زنجان (Safarloo and Hemmati 2014) و از نخود در لرستان (Adeli 2012)

$$
\text { ززارش شده است. اين گونه براى اولين بار از كانولا در ايران ززارش مىشود. }
$$

\section{Fusarium culmorum (W. G. Smith) Sacc.}

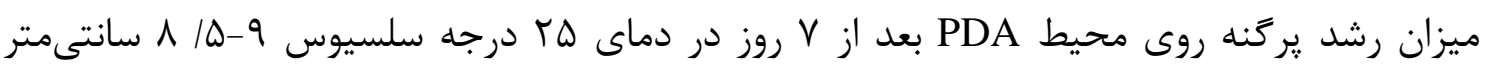
است و در دماى • ب درجه سلسيوس V/D-A سانتىمتر بود. ميسليوم هوايى يريشت و در بعضى جدايهها يراكنده و به رنت سفيد مايل به زرد و اغلب زرد مايل به قهوهاى و كاهى قرمز مىباشد و 
رنگ سطح زيرين بر گنه قرمز تا قرمز جكَىى است. كنيديوفورها در اين گونه به صورت منوفياليد ساده

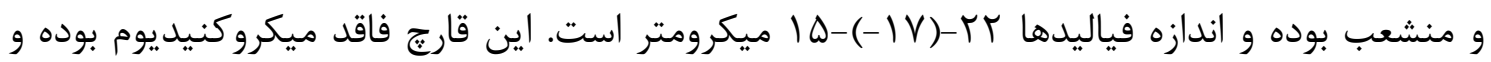
بوى خاصى دارد. ماكرو خميده تا كمى خميده و ياخته انتهايى نسبتاً نوى تيز بوده و ياخته پايه

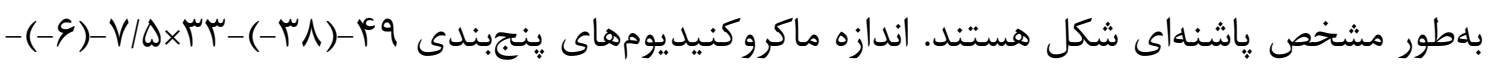
P/ F ميكرومتر مىباشد. كلاميدوسيورهاى اين قارج به صورت منفرد، جفتى، زنجيرى و تودهاى و به شكلهاى كروى تا نيمه كروى روى محيطهاى كهنه PDA و SNA تشكيل شد.

مشخصات اين زونه با آنجه در منابع ( Booth 1971, Burgess et al. 1994, Gerlach and Nirenberg 1982, Nelson et al. 1983, Seifert 1996, Summerell et al. 2003, Leslie and F. sambucianum ممكن است با F. culmorum ذكر شده مطابقت داشت. كونه (Summerell 2006 F. و F. crookwellens اشتباه شود و از آنجايى كه اين كونه رشد سريعتى نسبت به sambucianum مى كند. اين گَونه موجب يوسيدگى طوقه، ريشه و بلايت خوشه غلات و ساير گياهان مىشود و توليد آستروئيد و ميكوتوبينهايى مانند مونيلى فورمين، داكسى نيوالنول، تريكوتسين، فوزاريك اسيد C و زيرالئون مى كند(Leslie and Summerell 2006)

\section{Conclusion}

نمونسهـــاى جمـع آورى شــده از ريشه و طوقه كانولاى مناطق مختلف استان لرستان، حاوى شش كونه F. oxysporum, F. diversisporum, F culmorum, F. acuminatum شامل: Fusarium

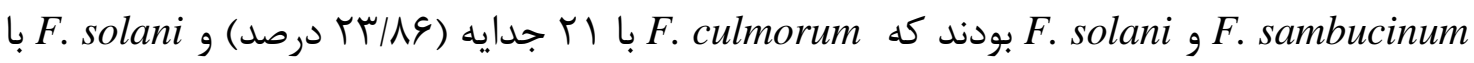
V جدايه (V/9ه درصد) به ترتيب بيشترين وكمترين فراوانى را داشتند. كانولا براى نخستين بار به

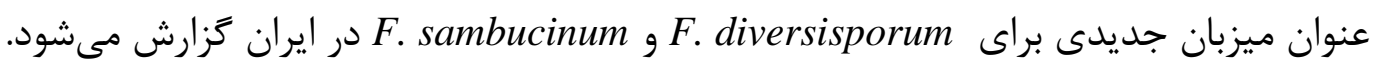

\section{References}

Adeli N, Darvishnia M, Dehghani A (2012) Identification of Fusarium fungal agents involved in pea root and crown in Lorestan province. The First National Conference on Sustainable Development of Agriculture and Healthy Environment, Hamedan. (In Persian).

Azizi M, Soltani A, Khavari Khorasani S (1999) Rape Crops (Physiology, Agronomy, Breeding and Biotechnology). Mashhad Jahade Daneshgahi Publication, Mashhad, Iran. (In Persian). 
Booth C (1971) The Genus Fusarium. Common Wealth Mycological Institute, Kew, $\mathrm{UK}, 237 \mathrm{p}$.

Burgess LW, Summerell BA, Bullock S, Gott KP, Bakhous D (1994) Laboratory Manual for Fusarium Research. Fusarium Research Laboratory. Department of Crop Science, University of Sydney and Royal Botanic Gardens, 133p.

Darvishnia M (2006) Taxonomic study and genetic diversity of Fusarium species of Liseola related to gramineous, $\mathrm{PhD}$ thesis. Tarbiat Modares University, Tehran.

Darvishnia M, Alizadeh A, Zare R (2010) Three new Fusarium taxa isolated from gramineous plants in Iran. Rostaniha 11:55-67. (In Persian with English Abstract).

Ershad D (2010) Fungi of Iran. Ministry of Jihad-e Agriculture, Iranian Research Institute of Plant Protection, Iran. 53p.

Gerlach W, Nirenberg H (1982) The genus Fusarium: Pictorial atlas. Kommissionsverlag Parey, Berlin.

Kimber DS, McGreogor DI (2004) Oilseed rape: Physiology, Agronomy, Breeding, Biotechnology. In: M Azizi, A Soltani, S Khavari Khorasani (eds.). Jihad Daneshgahi Mashhad Press. Mashhad University, Mashhad, Iran. (In Persian).

Larki Z, Farrokhi Nejad R (2015) Identification of Fusarium species associated with root and crown canola in Khuzestan province. World of Microbes 8:168-172. (In Persian with English Abstract).

Lee YM, Choi YK, Min BR (2000) PCR-RFLP and sequence analysis of the rDNA ITS region in the Fusarium ssp. Journal of Microbiology 32:66-73.

Leslie JF, Summerell BA (2006) Fusarium laboratory workshops-a recent history. Mycotoxin Research, 22:73-74.

Mansoori B, Ravanlou A, Nooralahi KH, Azadbakht N, Jafaree H, Ghalandar M (2002) Common root rot of wheat, a prevalent disease in West Azarbaijan, Ilam, Lorestan, Markazi and Zanjan. Proceeding of $15^{\text {th }}$ Iranian Plant Protection Congress, 7-11 September, Kermanshah, Iran, P.41.

Nelson PE, Desjardins AE, Platnner RD (1993) Fumonisins, mycotoxins produced by Fusarium species: biology, chemistry and significance. Annual Review of Phytopathology, 31:233-252.

Nelson PE, Toussoun TA, Marasas WFO (1983) Fusarium species, An Illustrated Manual for Identification. Pennsylvania State University Press, University Park, $193 p$.

Nirenberg HI, O'donell K (1998) New Fusarium species and combination within the Gibberella species complex. Mycology 90:43-458. 
Ravanlou A (2000) Etiology of root and foot rot of Wheat in west Azarbaijan. Proceedings of $14^{\text {th }}$ Iranian Plant Protection Congress, 5-8 September, Isfahan, Iran: p.219.

Safaee D (2004) Fungi associated with root and crown root of wheat in Kermanshah Province. Proceedings of 16th Iranian Plant Protection Congress, 28 Augest-1 September, Tabriz, Iran, p.38.

Safarloo Z, Hemmati R (2014) Identification and pathogenicity of Fusarium species associated with bean root rot in Zanjan Province. Applied Research Plant Protection, 3:78-92. (In Persian with English Abstract).

Seifert K (1996) Fusarium Interactive Key. Agriculture and Agri-Food Canada. 65p.

Summerell BA, Salleh B, Leslie JF (2003) A utilitarian approach to Fusarium identification. Plant Disease 87:117-128.

Vafaei H, Farokhinejad R, Darvishnia M (2001) Fusarium species associated with root and crown wheat and barley in Khuzestan Province. Science Journal Agriculture 24:101-125.

Zare R, Ershad D (1997) Fusarium species isolated form cereals in Gorgan area. Iranian Journal Plant Pathology 33:1-14. 